Mavi Atlas, 6(1)/2018: 185-204.

Araştırma Makalesi | Research Article

Makale Geliş | Received: 20.02.2018

Makale Kabul | Accepted: 09.03.2018

DOI: $10.18795 /$ gumusmaviatlas.413245

Sedef BULUT

Dr. Öğr. Üyesi

Ankara Üniversitesi, Türk İnk1lâp Tarihi Enstitüsü, Ankara-Türkiye

Ankara University, Institute of Turkish Revolution History, Ankara-Turkey

ORCID: 0000-0002-5525-584X

sbulut@ankara.edu.tr

\title{
38. Enlemde Güç Mücadelesi: Kore Savaşı ve Türkiye’deki Tezahürleri
}

\section{$\ddot{O} \mathbf{z}$}

II. Dünya Savaşı'nın akabinde dünya Soğuk Savaş diye nitelendirilen yeni bir döneme girmiştir. Bu dönemde dünya, başını Amerika Birleşik Devletleri'nin çektiği Batı Blok'u ile Sovyet Rusya'nın önderliğinde teşekkül eden Doğu Blok'u arasında hemen her alanda yaşanan rekabete sahne olacaktır. Bu iki kutuplu dünyada ve Sovyet tehdidi karşısında tercihini Batı Blok'undan yana kullanan Türkiye'nin dış̧ politikasında Kore Savaşı oldukça önemli bir yere sahiptir. Zira Türkiye'nin dış politikasında belirleyici bir role sahip olan NATO üyeliği ve ABD müttefikliği büyük ölçüde bu savaşla teşekkül etmiştir. Bu makalede, Kore Savaşı'na giden süreçte Türk hükümetlerinin dış politikası ana hatlarıyla betimlendikten sonra, savaşın Türk dış politikasındaki yerine değinilecektir. Makalenin asıl ağılık noktasını ise Demokrat Parti'nin Kore Savaşı'na asker gönderme kararının muhalefet ve kamuoyu tarafından nasıl karşılandığının tespiti oluşturmaktadır. Bu minvalde dönemin basını, sivil toplum kuruluşları ile iktidar ve muhalefetin meseleye yaklaşımları tahlil edilecektir. Arşiv vesikaları, süreli yayınlar ve telif-tetkik eserlerden istifade edilerek oluşturulan bu çalışmanın Türk dış politikası tarihi literatürüne katkı yapması beklenmektedir.

Anahtar Kelimeler: Kore Savaşı, Demokrat Parti, Cumhuriyet Halk Partisi, Kamuoyu.

\section{Power Struggle in $38^{\text {th }}$ Latitude: Korean War and Reflections in Turkey}

\begin{abstract}
After Second World War, the world has entered a new phase of what is referred to Cold War. In this period, the world will be the scene of competition between the West Block, headed by the United States, and the East Block, led by Soviet Russia. In this bipolar world, the West Block and the Korean War has a very important role in Turkey's foreign policy against the threat of Soviet Union Because NATO membership, which have a decisive role in Turkey's foreign policy and being an ally of US have largely depended on this war. In this article, the foreign policy of the Turkish governments will be outlined in the process leading up to the Korean War, and then the importance of this war for the Turkish foreign policy will be mentioned. The main focus of the article is the reflections on Democratic Party's decision to send troops to the Korean War by the opposition and the public. In this way, the reactions of the press, nongovermental organizations, power and opposition will be analyzed. It is expected that this work, which is made up of archive documents, periodicals and copyrighted works, will contribute to the history of Turkish foreign policy.
\end{abstract}

Keywords: Korean War, Democratic Party, Republican People's Party, Public Opinion. 


\section{Giriş}

II. Dünya Savaşı, 20. Yüzyılın en yıkıcı savaşı olarak tarihe geçmiştir. Çoğunluğu sivil olmak üzere milyonlarca insanın hayatını yitirdiği bu savaşın tesirlerini, savaşa dâhil olsun ya da olmasın, neredeyse bütün ülkeler hissetmiştir. Savaş bitse de barışa kavuşmak çok kolay olmamış, milletlerarası gerginlikler devam etmiş ve bu dönem "soğuk savaş" dönemi olarak ifade edilmiştir. II. Dünya Savaşı sonrasında milletlerarası politikanın yapısı değişmiş, dünya siyasetine Amerika Birleşik Devletleri (ABD) ve Sovyet Rusya arasındaki rekabet damga vurmuştur. Milletlerarası ilişkilere doktrin ve ideoloji unsuru dâhil olmuş, Komünist düzenin karşı cephesinde yer alan ülkeler, Sovyet yayılmacılığına karşı mücadele etmeye başlamıştır. Dünya siyasetinin ekseni genişlemiş, Çin Halk Cumhuriyeti ve Hindistan gibi kalabalık nüfuslu ülkelerin ortaya çıkışı ve Japonya'nın Asya'da ekonomik gücü ile tekrar sivrilmesi Asya kıtasını cazibe noktası haline getirmiştir (Armaoğlu 1993: 419-421).

II. Dünya Savaşı'ndan sonra Türkiye'de açık bir şekilde Boğazlar yüzünden Sovyet tehdidine maruz kalmıştı. 1946 yılında Sovyetler üç ana doğrultuda yayılma çabası içerisindeydi. İran üzerinden Ortadoğu petrolleri ve Basra Körfezi ile Hint Okyanusu, Türkiye üzerinden Boğazlar, Ege Denizi ve Doğu Akdeniz ve Yunanistan üzerinden ise Doğu Akdeniz (Armaoğlu 1993: 441). Bu anlamda ABD’nin Missouri adlı zırhlı gemisinin, 5 Nisan'da 1946'da İstanbul'a gelmesi ve ABD'li kumandanların dönemin Türkiye Cumhuriyeti Cumhurbaşkanı İsmet İnönü'yü ziyaret etmeleri, TürkAmerikan ilişkileri açısından oldukça önemlidir. Amerikan filosunun ziyareti, Türk basınında geniş yer bulmuş ve bu ziyarete Türkiye-ABD dostluğunun gelişmesi açısından büyük önem atfedilmiştir (Cumhuriyet, 6 Nisan 1946).

1947 yılında İngiltere'nin ABD’ye verdiği Yunanistan ve Türkiye hakkındaki iki memorandum ise önemli bir kırılma noktasıdır. Bu memorandumda, Türkiye'nin Batı savunması için önemine dikkat çekilmiş, ekonomik ve askerî yardım yapılması gerektiği vurgulanmıştır. ABD Başkanı Harry Truman da, Amerikan Kongresinden, Türkiye ve Yunanistan'a yardım yapılması hususunda kendisine yetki verilmesini istemiştir. Kongre tartışmaları sırasında Amerikan dışişleri yetkilileri, Türkiye'nin Sovyet 
baskısında kalmasının, Boğazlardan Çin'e kadar bütün Ortadoğu ve Asya'yı tehlikeye düşürdüğünü vurgulamıştı. Neticede Yunanistan'a 300 milyon, Türkiye’ye ise 100 milyon dolarlık askeri yardım yapılması kararlaştırılmıştı (Armaoğlu 1993: 442).

Sovyet yayılmacılığına karşı çeşitli stratejiler geliştiren ABD, öncelikli olarak Sovyet tehlikesine maruz kalan devletlere askerî destek vermeği hedeflemişti. Ancak daha önemlisi $\mathrm{ABD}$, savaşın yarattığı yıkımın, yokluğun ve manevi çöküntünün, ülkeleri Sovyetler karşısında zayıf bıraktığını görmüştü. Dolayısıyla, Avrupa'da ve Japonya'da harap olmuş sanayi kuruluşlarının, çiftliklerin ve kentlerin yeniden kurulmasına imkân verecek geniş kapsamlı bir ABD ekonomik yardım planı Sovyetleri uzun bir süre bulundukları yerde "tutma" hususunda daha etkili olacaktı (Kennedy 1998: 439-440).

Bu doğrultuda, ABD Dışişleri Bakanı George Marshall, 5 Haziran 1947'de verdiği nutukta, Avrupa ülkelerinin kendi aralarında bir işbirliğine girmelerini, birbirlerinin eksikliklerini kapatmalarını istemişti. Eğer bu işbirliği neticesinde açık ortaya çıkarsa bunu da ABD kapatmayı taahhüt ediyordu (Armaoğlu 1993: 444).

12 Temmuz 1947'de Paris’te Fransa Dışişleri Bakanlığı binası “Quai d'Orsay”de bir araya gelen 16 Avrupa ülkesi ${ }^{1}$ temsilcileri, Avrupa'nın acil ihtiyaçlarını belirlemek ve karşılamak için, ABD’nin istediği biçimde Avrupa Ekonomik İşbirliği Teşkilatını kurdu. Bu ülke temsilcileri, ihtiyaçlarını gösteren ortak bir rapor hazırlayarak aynı yılın Eylül ayında ABD'ye sundu (Ertem, 2009: 391). ABD, bu program üzerine 3 Nisan 1948'de Dış Yardım Kanunu çıkararak, ilk yılda 6 milyar dolarlık bir ekonomik destekte bulundu.

Truman Doktrini ve Marshall Planı, ABD’nin almış olduğu ilk tedbirlerdi. Ancak ABD, 1948 'den itibaren Sovyetlerin saldırgan tutumunun artması üzerine, daha etkili bir mücadele ve "Sovyet yayılmasını durdurmak" amacı ile 4 Nisan 1949'da, 12 Batı ülkesi ile Kuzey Atlantik Paktı, NATO’yu kurdu. Bu pakta göre ise içlerinden birisine yapılmış saldırı hepsine yapılmış sayılacaktı (Armaoğlu 1993: 449).

\footnotetext{
${ }^{1}$ Bu ülkeler şunlardır: Avusturya, Danimarka, Belçika, Yunanistan, İzlanda, İrlanda, İtalya, Lüksemburg, Hollanda, Norveç, Portekiz, İsveç, İsviçre, Türkiye, İngiltere ve Fransa.
} 
Truman Doktrini ve Marshall Planı çerçevesinde gelen yardımlarla birlikte Türkiye daha Cumhuriyet Halk Partisi (CHP) döneminde, ABD ile yakınlaşmaya başlamıştı. 1950'lerde Demokrat Parti (DP) döneminde ise Türkiye'nin Kore’ye asker göndermesi, ABD ile olan dostluğu adeta zirveye taşıyacaktı (Çavdar 2000: 34).

\section{Soğuk Savaş’ın İlk Sıcak Çatışması: Kore Savaşı (1950)}

II. Dünya Savaşı sonrasında ABD ile Sovyet Rusya arasında yapılan anlaşmaya göre Kore; ABD, Sovyet Rusya, İngiltere ve Çin'in ortak vesayetinde bir statüde bulunacaktı. Ancak 1945 yılında Potsdam Konferansı'nda, Sovyet Rusya, Uzak Doğu savaşına katılmaya karar verince, askerî harekât açısından Kore toprakları 38. enlem çizgisinde ikiye ayrıldı. Toprakların kuzeyi Sovyet, güneyi ise ABD askerî sahası olarak kararlaştırıldı. Hemen harekete geçmeyen Sovyetler, ABD’nin Hiroshima ve Nagasaki'ye atom bombası atmasının ardından Japonya'ya savaş ilan ederek askerlerini Kuzey Kore'ye, 38. enleme doğru ilerletti ve böylece Kore fiilen ikiye bölündü. Bütün müzakerelere rağmen birleşme sağlanamayınca, 10 Mayıs 1948'de ABD güney Kore'de seçim düzenledi ve Syngman Rhee'nin başkanlığında Güney Kore Cumhuriyeti kuruldu. Sovyetler de bir seçim yaptı ve 9 Eylül 1948'de Kuzey Kore Halk Cumhuriyeti kuruldu (Armaoğlu 1993: 454).

Kore'de bu gelişmeler yaşandığı esnada Çin'de de Mao'nun önderliğinde Çin Halk Cumhuriyeti kurulmuştu (Çavdar 2000: 35). Çin'in, Komünist rejimi idaresine girmesi, Sovyetlerin Asya kıtasındaki durumunu güçlendirmişti. ABD’yi Asya'dan uzaklaştırma zamanının geldiğini düşünen Sovyetlerin talimatıyla, 25 Haziran 1950 sabahından itibaren Kuzey Kore güçleri, 38. enlemi geçerek Güney Kore’ye saldırdı. Birleşmiş Milletler Güvenlik Konseyi, bu olayı barışın çiğnenmesi olarak niteleyerek silahla karşı konulmasını kararlaştırdı. Bu karar üzerine Komutanlığına, General MacArthur'un getirildiği, çeşitli devletlerden askerlerin oluşturduğu bir Birleşmiş Milletler Gücü meydana getirildi (Armaoğlu 1993: 455). 


\section{Demokrat Parti İktidarı ve Türkiye’nin Kore’ye Asker Göndermesi}

II. Dünya Savaşı sonrasında, Boğazlar konusunda Sovyet baskısı ve tehditlerine maruz kalan Türkiye, bu tehlikeye karşı denge arayışına girmişti. Henüz, CHP'nin iktidar olduğu bu dönemde NATO üyeliği önemli bir çıkış yolu olarak görülmekteydi. 1950 Mayısında iktidara gelen DP ise NATO üyeliğini ve Amerika'nın yanında olmayı bir hedef haline getirmişti. Bu tutumda şüphesiz Türkiye'nin maruz kaldığı Sovyet baskısı ve duyulan güvenlik endişesi kadar, bu konunun DP için önemli bir iç politika malzemesi olması da etkili olmuştu. DP liderleri, 1950 seçim kampanyası sırasında yaptıkları konuşmalarda Türkiye'nin NATO'ya katılmasının aynı zamanda demokratik düzenin geleceğini güvence altına almak açısından önemli olduğuna vurgu yapmışlardı ${ }^{2}$.

DP'nin Başvekili olarak Adnan Menderes, 29 Mayıs'ta Türkiye Büyük Millet Meclisi'nde (TBMM) hükümet programını açıklamıştı. Birleşmiş Milletler idealine olan bağlılığını dile getiren Menderes, İngiliz - Fransız ittifakına ve Amerika ile sıkı dostluk bağına sık sık vurgu yapmıştı (Öztürk 1968: 363). DP, parti programında da dış politika konusunda: milletler birliği amacını hedef tutan barışçı ve açık bir dış siyaset üzerinde hassasiyetle durulmuştur. Parti programının 18. Maddesinde dış politika ideali olarak, milletlerin hukuk eşitliği, milletlerarası siyasi, iktisadî ve kültürel işbirliği, kolektif güven ve iyi komşuluk ilişkileri üzerinde durulurken, barışçı ve açık dış siyasetin millet menfaatlerine en uygun ve gerçekçi yol olduğuna da dikkat çekilmişti (DP Tüzük ve Program, 1949). Dışişleri Bakanı Fuat Köprülü'nün Mayıs sonunda Brüksel'deki İkinci Dünya Harbi'nden beri Batı'ya yönelmiş olan dış siyasetimiz son seçimler neticesinde, bu istikamette daha faal bir şekil alacaktır şeklindeki açıklaması DP'nin dış politikası hakkında önemli ipucu vermişti (Bulut 2008: 40).

DP Hükümetinin iktidara gelir gelmez dış politikada karşılaştığı ilk önemli sorun, 25 Haziranda patlak veren Kore Savaşı ${ }^{3}$ olmuştu. Kuzey Kore'nin ani saldırısı ve Seul'u

\footnotetext{
${ }^{2}$ Ayrıntılı bilgi için Bkz., (Bulut 2008: 40).

3 Kuzey Kore silahlı kuvvetleri, 25 Haziran 1950'de sabah saat 4:00 'de Ongjin Yarımadasını bombalayarak Güney Kore'ye taarruza başlamıştır. Saat 8:00 sularında da 38. paraleli geçerek Güney
} 
işgali ile ortaya çıkan gelişmeler, Türk Hükümeti ve basınında Komünist güçlerin Uzak Doğu'da yayılması olarak değerlendirilmişti. Dolayısıyla hükümet programında dış politika konusunda inandıkları ilkeleri açık bir şekilde ortaya koyan DP yöneticileri, Kore'deki gelişmelere kayıtsız kalmamışlardı (Albayrak 2004: 411).

Kore Savaşı patlak verdiği andan itibaren Türk kamuoyu bu meseleye büyük bir ilgi göstermişti. Ortaya çıkan gelişmeler endişe ile takip edilmiş, özellikle de Kore Savaşı'nın, III. Dünya Savaşı'na neden olup olmayacağı konusu büyük heyecan yaratmıştı (Cumhuriyet, 26 Haziran 1950). Bu dönemde Amerika'nın İstanbul Konsolosunun bir saldırı halinde Amerikan vatandaşlarının İstanbul'u nasıl terk edeceklerine dair bir tebliğ yayınlaması ve buna basında yer verilmesi (Cumhuriyet, 14 Temmuz 1950) kaygı düzeyini daha da arttırmıştı.

Kamuoyuna hâkim olan endişe ile birlikte basında yoğun bir şekilde Kore'ye yapılacak yardımın şeklinin ne olacağı konusunda tartışmaların sürdüğü bir sırada, 18 Temmuz 1950'de Yalova'da, Cumhurbaşkanı Celal Bayar'ın başkanlığında, Başbakan Adnan Menderes, Bakanlar ve Kuvvet Komutanlarının katıldığı kamuoyunun ilgisini çeken bir toplantı yapılmıştı (Cumhuriyet, 19 Temmuz 1950). Her ne kadar Yalova toplantısı sonrasında Başbakan, gazetecilerin sorularına Türk Silahlı Kuvvetlerinin güçlendirilmesi hususunda alınacak yeni tedbirlerin konuşulduğu şeklinde bir cevap vermişse de, kamuoyundaki yaygın kanaat aslında asker gönderme konusunun görüşüldügü yolundaydı. Dönemin basını bu konuya geniş yer verirken, bu toplantı DP'nin bu konuda yakın gelecekte gerçekleştireceği icraatlara dair de ilk ipucu olmuştu (Ulus, Milliyet, Cumhuriyet, 19 Temmuz 1950).

Güney Kore'nin içinde bulunduğu zor durum karşısında Birleşmiş Milletler de harekete geçmişti. BM Genel Sekreteri Trygve Lie'nin Güvenlik Konseyinin, Güney Kore'ye yardım edilmesini isteyen 27 Haziran 1950 tarihli ve 473 sayılı kararını Türk Hükümetine ulaştırması ile birlikte ise DP iktidarının bu yöndeki faaliyetleri hız

Kore'ye taarruz edince, Güney Kore Cumhuriyeti aynı gün saat 11:00 de Kuzey Kore’ye savaş ilan etmiştir. 27 Haziran 1950 de ise BM Güvenlik Konseyi, Güney Kore’ye yardım etmeleri için üye ülkelere çağrıda bulunmuştur (Kore'de Türk Muharebeleri 2012: 23). 
kazanmıştı. Dışişleri Bakanı Fuat Köprülü 30 Haziran 1950 tarihinde bu konuyu TBMM'nin gündemine taşımış ve özetle söz konusu karara olumlu yanıt verdiklerini söylemişti (Albayrak 2004: 411).

Hükümet bu konuda çalışmalarını sürdürürken bir yandan da Kore meselesine karşı Amerikan kamuoyunun durumu tetkik edilmişti. Türkiye'nin Washington Basın Ataşeliği tarafından bir rapor hazırlanmış, Başbakan ve Başbakan yardımcılarına iletilmişti. Söz konusu raporda, Kore meselesi karşısında; Amerika'da, Başkan Truman'ın, muhalefetin, halkın, basının, ordunun, New York Borsasının vb. hususların tavırları analiz edilmişti ${ }^{4}$.

25 Temmuz akşamı, Bakanlar Kurulu, Ankara'da Cumhurbaşkanı Celal Bayar'ın başkanlığında toplanmıştı. TBMM Başkanı Refik Koraltan ve Genelkurmay Başkanı Orgeneral Nuri Yamut'un da katıldığı toplantıda, BM Genel Sekreteri Trygve Lie'nin yardım talebi karşısında alınan karar gereğince Dışişleri Bakanı Fuat Köprülü tarafından BM Genel Sekreteri Trygve Lie'ye bir telgraf çekilmişti. Bu telgrafa göre; Cumhuriyet Hükümeti barışı korumak ve Kore'de hizmet etmek üzere 4.500 mevcutlu silahlı bir savaş birliğini Birleşmiş Milletler emrine vermeye karar vermiştir. (BCA, 30.1.0.0102.630.9).

Başbakan Menderes'in Kore'ye asker gönderilmesi ile ilgili yapmış olduğu basın açıklaması Amerikan Senatosunda da yankı bulmuştu. Senatör Fulbright, Kongrede yaptığ1 konuşmada Menderes'in verdiği demeci, Türkiye'de gerçekleşen aydın ilerlemenin bir delili olarak görmüş ve bu demecin tutanağa geçmesini talep etmişti. Aynı şekilde, Senatör Mundt bu demeci cesaret verici ve takdire şayan olarak değerlendirmiş ve tutanağa geçirilmesini istemişti. Neticede Başbakan Menderes'in demeci bu iki senatörün gayretleri ile Amerikan Kongresinin 9 Ağustos 1950 tarihli tutanağına geçirilmişti (BCA, 30.1.0.0-102.630.9). Menderes Hükümetinin aldığı bu tarihi kararın ardından İngiltere, Yeni Zelanda ve Avustralya da Kore'ye asker göndermişlerdir (Bağc1 1990: 27).

\footnotetext{
${ }^{4}$ Ayrıntılı bilgi için Bkz. (Başbakanlık Cumhuriyet Arşivi (BCA), 30.1.0.0-102.630.6.
} 


\section{Kore’ye Asker Gönderme Kararına Tepkiler}

\section{Muhalefetin Tutumu}

Hükümetin, 25 Temmuz 1950'de aldığı asker gönderme kararı Türk kamuoyundaki mevcut heyecanı zirveye taşımıştı. Başta DP il ve ilçe başkanlıkları olmak üzere yurdun her köşesinden, çeşitli meslek gruplarından ve şahıslardan, Hükümetin kararını onaylayan telgraflar Başbakanlığa gönderilmiști. Bu telgraflarda Hükümetin kararının büyük coşku ile karşılandığı görülmektedir. Söz konusu telgraflarda dünya sulhunun korunması öncelikli olarak vurgulanmıştı. DP teşkilatlarından gelen telgraflarda ise Kore'ye asker gönderilmesi kararına karşı yapılan olumsuz propagandaların da eleştirildiği görülmektedir (BCA, 030.01.00-0017.98.94-129).

Kore’ye asker gönderilmesi kararının ardından CHP Genel İdare Kurulu, İnönü başkanlığında toplanarak meseleyi görüşmüştü. Başta CHP olmak üzere TBMM'nin onayına sunulmadan yurtdışına asker gönderilmesi muhalefet tarafından bir Anayasa ihlali olarak görülmüştü. $\mathrm{Bu}$ yönü ile iktidar ve muhalefet arasında sert tartışmalara neden olan mesele defalarca meclis gündemine gelmişti.

Muhalefetin bu eleştirisi karşısında DP Hükümetinin temel argümanı, anayasanın savaş ilanı yetkisini TBMM'ye verdiğini ancak hangi hususların savaş ilanı kapsamında olduğunu belirtmediği yönündeydi. Ayrıca Hükümet, asker gönderme kararı almış olmakla birlikte savaş ilan etmemişti. DP Hükümeti, Birleşmiş Milletler Adlaşması'nın 39, 41 ve 42'nci maddelerine göre Birleşmiş Milletler emrine askeri birlik vermenin bir savaş kararı sayılamayacağını iddia etmiş ve Kore'ye asker gönderme kararını savunmuştu. CHP ise savaş ve barış gibi önemli kararların anayasanın 26. maddesi uyarınca ancak TBMM'de alınması gerektiğini öne sürerek durumu Anayasa ihlali olarak değerlendirmişti (Kuşoğlu 2011: 11).

Hukukçu Profesör Nihat Erim'in, Ulus gazetesinde neşredilen değerlendirmesine göre Kore’ye asker göndermek harp ilanı değildir diyerek işin içinden sıyrılmak mümkün değildi. Birleşmiş Milletler Anayasası'na göre; TBMM'den peşin alınmış bir 
onay yoktu. Türk Anayasası, Bakanlar Kuruluna, fiili harp hareketlerine Meclisten karar almaksızın katılma yetkisi vermemişti (Ulus, 9 Aralık 1950). Erim’e göre dava, TBMM'nin Anayasaya dayanan haklarını koruma davasıydı. Milletin istikbalini olumlu ya da olumsuz etkileyecek kararları Hükümet kendi başına almaya alışmamalıydı (Ulus, 8 Aralık 1950).

1950'li yıllar dış politika açısından genel olarak değerlendirildiğinde, esasında önceki iktidar partisi CHP ile iktidarın yeni sahibi DP'nin bu konuda genellikle uyum içerisinde olduğu göze çarpmaktadır. Bu politikanın ortak noktalarını Her türlü sol faaliyete karşı olmak, Sovyet karşıtı tutum izlemek ve ABD'nin politik çizgisini takip etmek şeklinde sıralamak mümkündür (Çavdar 2000: 31).

Zaten, DP'ye yönelik eleştiriler ana hatlarıyla değerlendirilecek olursa; Kore'ye asker gönderme kararının aslında daha çok içerik açısından tartışıldığı görülmektedir. CHP'nin en çok üzerinde durduğu konulardan birisi de durumun TBMM'de tartışılmaması kadar, CHP Genel Başkanı İnönü'nün fikrinin sorulmamasıdır. DP adına muhalefetin eleştirilerine cevap veren Dışişleri Bakanı Fuat Köprülü ise Böylesine milli bir davayı iç siyaset meselesi haline getirmeyi üzüntü ile karşıladığını söylerken, bu kararın yalnızca Komünist basın tarafından eleştirildiğini vurgulamıştır. DP yöneticileri, başta CHP olmak üzere bu kararı eleştiren muhalefeti, solcu aydınlar tarafından 12 Mayıs 1950'de kurulan ve Türkiye'nin Kore'ye asker göndermesine karşı çıkan Barışseverler Cemiyeti ${ }^{5}$ ile aynı safta durmakla suçlamışlardı (Milliyet, 31 Temmuz 1950).

Kore'ye asker gönderme kararı TBMM'nin yaz tatiline girdiği bir sırada alındığı için bu karara karşı yapılacak ilk hukukî girişim Meclisi olağanüstü toplantıya çağırma teşebbüsü olmuştu. Bu teşebbüs özellikle Hükümet yanlısı gazeteler tarafından şiddetle eleştirilmişti. DP'nin adeta yayın organı olan Zafer gazetesi, hiçbir DP'linin bu çağrıya uymayacağını söylerken ${ }^{6}$ Cumhuriyet Gazetesi başyazarı Nadir Nadi de çok önemli bu

\footnotetext{
${ }^{5}$ Türk Barışseverler Cemiyeti'nin Kore'ye asker gönderilmesine muhalefet etmeleri hususunda ayrıntılı bilgi için bkz: (Özdemir ve Şendil 2016: 337-367).

${ }^{6}$ Ayrıntılı bilgi için Bkz. (Zafer, 1 Ağustos 1950).
} 
dış politika konusunun partiler arası bir mücadeleye dönüşmesini eleştirmiş, durumu idare etme açısından acemilik gösteren hükümete karşı anlayışı1 olunmasını istemişti (Cumhuriyet, 29 Temmuz 1950).

Akşam gazetesi yazarı Necmettin Sadak ise söz konusu tartışmayla ilgili olarak, Cumhuriyet tarihinde ilk defa görülen bu olay karşısında Meclise danışılmasının daha iyi olacağını ifade ederek, konu ile ilgili İngiliz Avam Kamarasındaki tartışmaları örnek göstermişti. Ancak yazar diğer yandan da Hükümet bir şekilde karar verdikten sonra münakaşaların devam etmesinin memleketin aleyhine olacağını savunmuştu (Akşam, 9 Ağustos 1950).

TBMM'yi olağanüstü toplantıya çağırma girişimleri yeterli sayı sağlanamadığı için sonuçsuz kalmıştı (Cumhuriyet, 10 Ağustos 1950). Millet Partisinin parlamentodaki tek üyesi, Kırşehir Milletvekili Osman Bölükbaşı ise konuyu TBMM'ye taşımayı başarmıştı. Bölükbaşı ve Mardin Bağımsız Milletvekili Kemal Türkoğlu, Kore'ye gönderilen savaş birliği hakkında 20 Kasım 1950 de Başbakan hakkında bir gensoru önergesi vermişlerdi. Meclis açıldı̆̆ından beri Hükümetin Mecliste bu konuda herhangi bir açıklamada bulunmaması, hissettiğimiz zarureti bir kat daha arttırmış ve bizi Kore'deki şanlı birliğimizin tarihimize yeni destanlar katmakta olduğu günlerde bir gensoru açılması teklifinde bulunmaya sevk eylemiştir sözleriyle (Bölükbaşı 2005: 131) amaçlarını ifade eden Türkoğlu ve Bölükbaşı'nın bu eylemi yeni bir gündem yaratmış ve kamuoyunu bir süre meşgul etmişti.

Vakit gazetesi yazarı Asım Us gensoru ile ilgili görüşlerini ifade ettiği makalesinde, CHP'nin de Kore'ye asker göndermek mecburiyetinde olmadığımızı ispata hakkı vardır derken Atlantik Birliğine dâhil olan ülkelerden dahi birlik göndermeyenler olduğuna dikkat çekmişti. Dolayısıyla bu meselenin de açık bir şekilde Meclis kürsüsünden tartışılması gerekmektedir (Vakit, 24 Kasım 1950).

Söz konusu önergede adı geçen iki milletvekili, bir emrivaki ile tatbik edilen bu kararın geri alınabileceğini asla düşünmediklerini ifade etmekle birlikte, Anayasa'ya aykırı bir karar alan mevcut hükümetin işbaşında kalamayacağını ifade etmişlerdi. 
Milletin gerçek temsilcilerinin milli hâkimiyet haklarını çiğnetmek gibi ağır ve tarihi bir mesuliyeti omuzlarına alamayacağı ifade edilen önerge karşısında hükümet adına çoğunlukla Adnan Menderes cevap vermişti (Bulut 2008: 41). ${ }^{7} \mathrm{Bu}$ önergeye karş1lık, İstanbul Milletvekili Mükerrem Sarol ve yedi arkadaşının Birleşmiş Milletler emrine Kore'ye silahlı kuvvetler gönderilmesi hususunda Hükümet tarafından verilen hukukî ve siyasî izahatın tasvip edilmesi yönünde verdikleri önerge ise, 11 Aralık günü oylanmış ve oyçokluğu ile kabul edilmişti (Ulus, 12 Aralık 1950).

Yaklaşık dokuz saat süren ve sert tartışmaların yaşandığ toplantıda 4500 kişinin hayatı üzerinde karar vermek hakkı yalnızca TBMM'ne aittir diyen Bölükbaşı'nın konuşması defalarca kesilmişti. İkinci defa kürsüye gelen Bölükbaşı bu konuşmasında ise Türkiye'nin emniyeti sağlanmadan asker gönderilmesine taraftar olmadığını bir kez daha vurgulamıştı (Kudret, 12 Aralık 1950). Gensoru önergesinde imzası olan Kemal Türkoğlu da Hükümete bu konu ile ilgili pek çok soru yöneltmişti. Bunların içinde kararın neden Resmi Gazete'de yayınlanmadığı ve Kore'ye gönderilen birliğin standart birlik olup olmadığı soruları dikkat çekicidir. Bu sorulara cevap veren Başbakan, bu sorunun Hükümeti zor duruma sokmak için sorulduğunu öne sürerken Memleket menfaatleri bu soruya cevap vermemeyi icap ettirmektedir şeklinde açıklama yapmışt1 (Yeni İstanbul, 12 Aralık1950; Her gün, 12 Aralık 1950).

Hükümete verilen itimat oyu neticesinde ise Mecliste teşekkür konuşması yapan Adnan Menderes, alınan bu kararın gayrı meşru olmadığından emin olduğunu ifade ederek bundan sonra memleket zararına olan bu çeşit "zehirli propagandaların" durmasını temenni etmişti (TBMM Tutanak Dergisi 11.12.1950: 136-199).

CHP ve MP'nin aleyhte eleştirilerine rağmen, Milli Kalkınma Partisi (MP) Hükümete her konuda tam destek vermişti. MKP'nin Bergama Kurulu tarafından Adnan Menderes'e gönderilen bir mektup bu partinin görüşlerini açık bir şekilde ortaya koymaktaydı. Bu mektupta, gerek sözlü gerekse de yazılı olarak Hükümetin Kore politikası aleyhindeki her türlü faaliyetin, MKP tarafından şiddetle eleştirildiği

\footnotetext{
7 Ayrıntılı bilgi için ayrıca Bkz. (TBMM Tutanak Dergisi, Dönem IX, c.3,11.12.1950: 136-199.)
} 
görülmektedir. Bu mektup DP tarafından takdir ve memnuniyet ile karşılanmıştı (BCA 30.1.0.0-17.98.49).

Kore Savaşı'na katılma kararına en şiddetli tepki ise Behice Boran'ın başkanlığını yaptığı Türk Barışseverler Derneği'nden gelmişti. Adnan Cemgil'in de genel sekreter olduğu yaptığı Cemiyet, Hükümetin kararını bir bildiri ile protesto etmişti. Cemiyetin dağıttığı bildiriler toplatılırken, Behice Boran ve Adnan Cemgil hakkında soruşturma açılmıştı (Cumhuriyet, 30.07.1950).

Komünizme karşı mücadele başlatan Hükümet ise bu mücadelede en büyük desteği, yine basından ve Türk gençliğinden görmüştü. İstanbul, Ankara ve İzmir'de Hükümetin Kore ile ilgili kararını eleştiren yazı ve karikatürler yayınlayan on yedi mizah dergisi de komünizm propagandası yapmak, vatandaşları kışkırtacak nitelikte neşriyatta bulunmak gibi gerekçelerle kapatılmıştı ${ }^{8}$. Diyanet İşleri Başkanı Ahmet Hamdi Akseki de komünizm aleyhine bir açıklama yaparak hakiki bir müminin komünistlik fikriyle ve icraatıyla bağdaşabilmesinin mümkün olmadığını söylemiştir (Cumhuriyet, 26.08.1950).

Kore Savaşı ekseninde gelişen ve Barışseverler Cemiyetinin faaliyetleri ile ivme kazanan tüm muhalif hareketler, Hükümet tarafından Komünizm ile ilişkilendirilmişti. Bu süreçte de ciddi bir şekilde Komünizmle mücadele başlamıştı. Adalet Bakanı Halil Özyörük'ün başkanlığında toplanan komisyon, Komünizm ile ilgili yeni bir ceza kanunu hazırlamaya girişmişti. Yapılan toplantıda Komünizmin vatana ihanet ile cezalandırılmasında ısrar edilmiş, fiil ve hareketleriyle komünistliği ispatlanmış olanların, vatandaşlıktan çıkarılması ve yurt dışına sürülmesi konularında ısrarla durulmuştu (Basın, 12 Ağustos 1950).

Bütün bu faaliyetlerle birlikte ülkeye dışarıdan gelen yayınlar konusunda da hassas davranıldığı görülmektedir. Fransa'da Federation Syndicale Mondiale isimli kurum tarafından bastırılan Güney Kore İşçilerinin Durumu ve Birleşmiş Milletler Kore Komisyonunun Faaliyetleri isimli bültenlerin de yurda sokulması yasaklanmıştı. Söz

\footnotetext{
8 Ayrıntılı bilgi için Bkz. (Milliyet, 5 Ağustos 1950; Türk Dış Politikası 2003: 546).
} 
konusu yayınların mevcutlarının da toplatılmasına Bakanlar Kurulunca karar verilmişti (BCA 30.1.0.0-123.782.9-16.09.1950).

$\mathrm{Bu}$ süreçte, Barışseverler Cemiyeti askeri mahkeme tarafından kapatılmış, yöneticileri on ile on beş ay arasında değişen cezalara çarptırılmıştı (Çavdar 2000: 33). Barışseverler Cemiyeti üyelerinin hapis cezasına çarptırıldı̆̆ı kararda ise şöyle denilmektedir: Cemiyet gayesinin siyasi olmadĭ̆ hakkında beyanname verildiği halde, tamamen siyasi maksatlar güdüldüğ̈̈, Amerikalılarla dostluğumuzun bozulması gayesini taşıdıkları, Kore'ye hükümetin asker gönderme kararı karşısında yayınladıkları beyannamelerle halkın hükümete itimadını kırdıkları ve milli mukavemeti zaafa uğrattıkları zikredilmektedir (Milliyet, 31.12.1950).

\section{Kamuoyunun Tepkisi}

Muhalefetin tüm eleştirilerine rağmen asker gönderme kararı, ülke içinde genel olarak olumlu bir hava yaratmıştı. Türk Hükümetine Kore’ye asker göndermek ile ilgili teklif geldiği zaman, eski bir taksi şoförü olan Semih Yürüten Kore’ye gitmek amacıyla gönüllü asker toplama kampanyası başlatmış, bir hafta içinde 10 bin kişi gönüllü olmuştu (Cengiz 2014: 430-431).

Türkiye'deki en büyük öğrenci örgütlerinden birisi olan Türk Milli Talebe Federasyonu, kararı büyük bir memnuniyetle karşıladığını belirtirken, Türk Gençlik Teşkilatı da bu karara destek vermişti. İstanbul Üniversitesi Talebe Birliği, Komünizme karşı İstanbul'da bir toplantı düzenlemiş (Cumhuriyet, 05.08.1950), bu toplantıya muhalefet partilerinin yetkilileri de katılmıştı. Türkiye Milli Talebe Federasyonu ise Can Kıraç imzası ile yayınladıkları bildiride Hak ve hürriyet uğrunda girişilmiş olan bütün taahhütleri yerine getirmeyi kendine görev sayan bir milletin evlatlar olmaktan duyduğumuz gurur sonsuzdur diyerek bu konudaki görüşlerini ifade etmişlerdi (Akkaya 2012: 8).

Türk basınında ise Hükümetin Kore ile ilgili kararıyla ilgili hem lehte hem de aleyhte yazılar çıkmıştı. Eleştiren yazarların görüşleri, muhalefetin eleştirileri ile aynı 
doğrultuda olmuştu. $\mathrm{Bu}$ anlamda en çok CHP'nin görüşlerini dile getiren Ulus ve DP'nin fikirlerini neşreden Zafer gazeteleri karşılıklı polemiğe girmişti ${ }^{9}$. Cumhuriyet, Milliyet, Son Posta, Yeni Ístanbul ve Vatan gazeteleri bu kararı sonuna kadar desteklemiş ve bu yönde yayınlar yapmıştı (Bağcı 1990: 28).

$\mathrm{Bu}$ tarihe kadar Türkiye, ülke sınırları dışında bir askeri harekâta ya da müdahaleye katılmaktan kaçınmıştı (Bağcı 1990: 24). Türkiye, Kurtuluş Savaşı'ndan sonra ilk kez bir silahlı mücadeleye Kore Savaşı ile dâhil olurken, Amerika'dan sonra Kore'ye asker gönderen ilk devlet olmuştu. Basında Kore Savaşı ile ilgili haberlerin ve yazıların yer alması kamuoyunun ilgisini arttırmış, Kore’ye gönüllü olarak gitmek için Milli Savunma Bakanlığına binlerce dilekçe yazılmıştı (Ulus, 4 Eylül,1950). Kore Türk Tugayı'nın kadrosu 259 subay, 18 askerî memur, 4 sivil memur, 395 astsubay ve 4.414 erden oluşmuştu. Kadroya göre astsubay noksanı 1928 doğumlu kıta çavuşlarından karşılanmaya çalışılmıştı. Erler arasında Ermeni, Rum, Musevi ve Süryani asıllı 17 gayrimüslim vatandaş da bulunmaktaydı (Kore'de Türk Muharebeleri 2012: 32).

25 Eylül 1950'de İskenderun'dan yola çıkarak 17 Ekim'de Kore'ye giden askerler ile ilgili haberler savaş muhabirleri tarafından günü gününe basına duyurulmuştu. Özellikle Türk askerinin Kunuri başarısı toplumdaki heyecanı daha da arttırmıştı. Türkiye'nin birçok il ve ilçesinde coşkulu miting ve toplantılar düzenlenirken tebrik telgrafları çekilmişti. Bitlis, Çaycuma, Denizli, Mardin, Muğla, Eskişehir, Kars, Zonguldak gibi şehirlerde Hür insanlık ideali için savaşan askerleri anmak için toplantılar düzenlenmiş, şiirler ver marşlar okunmuştu (Milliyet, 4 Aralık 1950).

Ülkenin her yerinde Kore'deki askerler için dualar edilmiş, şehitler için mevlitler okutulmuştu. Kore şehitlerinin ruhuna ithaf edilmek üzere Türkiye Anıtlar Derneği İstanbul Şubesi tarafından 10 Aralıkta Süleymaniye Camiinde hatmi şerif ve mevlit okutulmasına karar verilmiş ve Hükümetin ileri gelenleri ile milletvekilleri de bu dini merasime davet edilmişti (BCA 030.1.0.0-123.782.9). Muazzam bir kalabalığın toplandığı camide 30 bine yakın kişi olduğu ileri sürülmüştür. Bu törene Diyanet İşleri

\footnotetext{
${ }^{9}$ Ulus ve Zafer Gazetelerinin karşılıklı polemiklerine örnek olarak Bkz. (Ulus, 8 Aralık 1950)
} 
Başkanı Ahmet Hamdi Akseki'nin yanı sıra Suudi Arabistan, Suriye, Lübnan, Afganistan, Pakistan ve Irak’ın Türkiye elçileri ile Mısır Başkonsolosu da katılmıştı (Milliyet, 11 Aralık 1950).

Ülkenin her köşesinde Türk askerinin kahramanlıkları anlatılırken bu ortam, Kore'ye asker gönderilmesini eleştiren muhalefete de yüklenilmesine neden olmuştu. Ankara ve İstanbul'da yapılan mitinglerde, Kore'de şehit düşen askerler için sayg1 duruşunda bulunulup, komünizme karşı mücadelede savaşa hazır olunduğu s1k s1k vurgulanmıştı (Yaman 2005: 242). Diyanet İşleri Başkanı da, Kore'deki savaşın inananlarla inanmayanlar arasında geçtiğini, iyilik ve kötülügün birbiriyle mücadele ettiğini söyleyerek bunun yalnızca bir toprak harbi olmadığına dikkat çekmişti (Milliyet, 11 Aralik 1950).

Türk askerinin başarıları ile ilgili haberler yurda ulaşmaya başladığı andan itibaren Kore'deki tugaya çeşitli hediyeler de gönderilmeye başlamıştı. Özellikle lise öğrencilerinin gönderdikleri hediyeler arasında bayrak gönderme ön plana çıkmaktaydı. Galatasaray Lisesi öğrencilerinin kendi kanları ile boyayarak gönderdikleri bayrak büyük ilgi görmüşs ${ }^{10}$, yurdun dört bir yanındaki eğitim kurumlarından öğrencilerin kendi emekleri ile oluşturdukları tablo, bayrak, harita vb. eserler Türk tugayına moral vermişti. Milli Savunma Bakanlığı da yılbaşı hediyelerinin Kore'ye nasıl ulaştırılacağına dair bir genelge yayınlamıştı (Milliyet, 21 Aralık 1950).

Radyoda da düzenli olarak Kore ile ilgili yayınlar yapılmıştı. Bu doğrultuda Türkiye'nin dört bir yanından insanın Kore'deki yakınlarına ve hemşerilerine ulaşmasında radyo aracı olmuştu. Başbakanlığa çekilen onlarca telgrafta halkın bu yöndeki istekleri, zaman zaman da şikâyetleri yer almıştı. Gerek CHP gerekse de DP, bu konudaki görüşlerini radyo aracılı̆̆ı ile de geniş kitlelere ulaştırma firsatını bulmuştu ${ }^{11}$.

\footnotetext{
${ }^{10}$ Ayrıntılı bilgi için Bkz., (Cumhuriyet, 18 Şubat 1950).

${ }^{11}$ Kore şehitlerinin radyo vasıtası ile anılması hususunda ayrıntılı bilgi için Bkz., (BCA 490.1.0.0$610.118, .1$ ).
} 
Türkiye'nin ilk kadın savaş pilotu Sabiha Gökçen'in, Milli Savunma Bakanlığı'nın Kore Bürosuna müracaatta bulunması da dönemin ilgi çekici olaylarındand1. Cumhurbaşkanı Celal Bayar'ı ziyaret ederek, bu konuda kendisine yardımcı olunmasını isteyen Gökçen'in bu kararı, Cumhurbaşkanı tarafından takdir ve tebrik ile karşılanmıştı (Milliyet, 11 Şubat 1951). Dünya basınının da dikkatini çeken bu olay Amerikan kamuoyunda da övgü ile karşılanmıştı. ABD'de yayınlanan New York kaynaklı bir habere göre, Türklerin Kore'de ortaya çıkan cesaret ve azimlerinin esasında yeni olmadığı vurgulanmıştı. Türk milletine yeni bir hayat bahşetmiş olan Atatürk idaresinde bu cesaret ve gayretin geliştiğine dikkat çekilen haberde Atatürk'ün manevi k1zı askeri pilot Sabiha Gökçen'in Kore’ye gitmek istemesinin doğal karşılanması gerektiği belirtilmişti. Bu haber çerçevesinde Atatürk sayesinde Türkiye'de gelişen kadın haklarına da ayrıca vurgu yapılmıştı (Milliyet, 11 Şubat 1951).

Türk Hükümetinin Kore’ye askerî yardım gönderme kararı özellikle Amerika'da son derece olumlu tepkilere yol açmıştı. Büyük gazeteler haberi birinci sayfadan verirken, yardım kararı radyolarda sık sık tekrarlanmıştı. NBC WPIX televizyon istasyonlarında da Türk ordusunun manevralarını gösteren eski filmlerden parçalar gösterilmişti (BCA 0.30.1.0.0-102.630.8).

Londra radyosundan yapılan yayınlarda da Türk ordusunun büyük bir hayranlık uyandırdığına değinilmişti. $\mathrm{Bu}$ dönemde $\mathrm{ABD}$ gazetelerinin sayfalarında Türkler kızllları korkutuyor, Türkler imdada koşuyor, Türkler düşmana tekrar saldırıyor gibi başlıklar sıkça görülmekteydi (Milliyet, 11 Aralık 1950).

Kore Savaşı boyunca başarı ve kahramanlıklarıyla dikkat çeken Türk askeri ile ilgili dünya basınında birçok habere rastlamak mümkündür. İspanyol Ariba gazetesi Türk askeri süngü takarak en güç vaziyetlere karşı koyuyor. Bir avuç Türk piyadesi, çok zor durumda bulunduğu bir sırada nasıl harb edileceğini dünyaya ögretmiştir şeklinde bir habere yer vererek takdirlerini dünyaya duyurmuştu. Şüphesiz bu ve benzeri örnekleri çoğaltmak mümkündür (Durak 2015: 333-334). 
France-Presse Ajansının Ankara muhabiri tarafından kendi ajansına çekilen telgraftaki şu sözler ise oldukça dikkat çekicidir: Türkiye için Kore Savaşı'ndan alınan başlıca ders şudur: Ĕger kltalar ve askerlerin savaşçı bir ruhları yoksa mükemmel silahlara sahip olmak hiçbir işe yaramaz. Türk kıtalarl, Amerikan askerlerinin aksine olarak, modern savaşta bu zihniyetin hatta teknikten bile daha önemli olduğunu göstermişlerdir. Amerikalılar gerilerken, Türkler süngü takıyorlardı... (BCA. 30.1.0.0102.630.11).

Kore'deki savaşlar iki y1l devam ettikten sonra 27 Temmuz 1953'te savaşı bitiren barış antlaşması Panmunjan'da imzalanmıştı. 6 Ocak 1951'de Ankara'dan tüm yabancı ülkelere gönderilen mesajlarda yaralı Türk askerlerinin Irak Habbaniyah üzerinden Türkiye’ye gönderildiği belirtilmekteydi (Atlı 2014:436).

\section{Sonuç}

1950 seçimleri sonrasında iktidarı CHP'den devralan DP, ilk hükümet deneyiminde dış politikada oldukça aktif bir siyaset uygulamıştı. DP'nin I. döneminde dış siyasette en çok tartışılan konular, 1950'de Kore'ye asker gönderilmesi ve 1952'de gerçekleşen NATO üyeliği olmuştu.

Esasen CHP döneminde başlatılan Batı ile ilişkilerin geliştirilmesi ve NATO'ya üye olma misyonu DP tarafından büyük bir coşkuyla devam ettirilmişti. Kore Savaşı'na asker gönderilmesi kararı ise Anayasa'ya aykırılık noktasında biçim olarak çok tartışılmış ancak içerik olarak sınırlı bir tepki görmüştü. Muhalefetin sınırlı tepkisine rağmen bu karar Türk halkı tarafından coşkuyla desteklenmişti. Hükümetin bu kararı aleyhindeki faaliyetlerse Komünizm ile ilişkilendirilmiş ve bu süreçte DP, Komünizmle mücadele propagandasına hız vermişti. Kamuoyunun bu tavrı muhalefetin tutumunun da giderek yumuşamasına neden olmuştu.

Türk askerinin Kore'de gösterdiği performans Türkiye'nin dünyadaki saygınlığını da arttırmıştı. Türk askerinin fedakârlığı ve cesareti tüm dünyaya örnek olmuş ve dış basında bu konu ile ilgili pek çok yayın yapılmıştı. 
Kore Savaşı, Kurtuluş Savaşı'ndan beri harp etmeyen Türk ordusu için de bir imtihan olmuştu. Neticede ise gücünden hiçbir şey kaybetmediğini dünyaya göstermişti. Türk kamuoyu Kore meselesini kendi davası olarak görmüş, dünya barışı için savaşmayı ise çok önemsemişti. Savaşın patlak verdiği andan itibaren yardım meselesi tartışılmış, mitingler, toplantılar ve dini törenlerle birlikte Kore hep gündemde tutulmuştu.

Özellikle 1954 yılında Cumhurbaşkanı Bayar ABD'de gösterişli törenlerle ve büyük bir ilgi ${ }^{12}$ ile karşılanmıştır ki, şüphesiz bu durumun ortaya çıkmasında Türk askerinin Kore'de gösterdiği üstün başarı ve fedakârlığın rolü büyüktür.

Kore'de Türk askeri sadece kahramanlığı ve cesareti ile değil aynı zamanda fedakârlığı ve insani yönleri ile de ön plana çıkmıştır. Türk askeri, savaştan mağdur olan Koreli çocuklara ve yaşlılara uzattığı yardım eli kadar, halka götürdüğü eğitim, sağlık vb. sosyal hizmetlerle de bu güne kadar gelen Türkiye-Güney Kore dostluğunun temellerini atmıştır.

${ }^{12}$ Ayrıntılı bilgi için Bkz. (Resmi Ziyaret, Türkiye Cumhurreisi Celal Bayar'ın Birleşik Amerika'yı Ziyareti’nin Hikâyesi (Ocak-Mart 1954). 


\section{KAYNAKÇA}

\section{Arşiv}

Başbakanlık Cumhuriyet Arşivi (BCA), Fon No: 030.01.00.0017.98.94, Belge No:(1-29); (BCA), FN: 30.1.0.0, Yer No: 102.630.6; FN: 30.1.0.0, YN:102.630.9.;) $\mathrm{FN}: 30.1 .0 .0, \mathrm{YN}: 17.98 .49$; FN: 30.1.0.0, YN: 123.782.9.,(16.09.1950), FN: 30.18.1.2, YN: 128.11.9; FN: 30.1.0.0, YN: 102.630.11.; FN: 0.30.1.0.0, YN: 102.6; FN: 490.1.0.0, YN: 610.118.1.

\section{Süreli Yayınlar}

Cumhuriyet, Her gün, Ulus, Milliyet, Kudret, Yeni İstanbul, Zafer.

\section{Resmi Yayınlar}

TBMM Tutanak Dergisi(11.12.1950). Dönem IX, 3 : 136-199.

\section{Telif ve Tetkik Eserler}

AKKAYA, Bülent (2012). "Türkiye'nin Nato Üyeliği ve Kore Savaşı", Akademik Bakış Uluslararası Hakemli Sosyal Bilimler Dergisi, 28: 1-20.

ALBAYRAK, Mustafa (2004). Türk Siyasi Tarihinde Demokrat Parti (19461960), Ankara: Phoenix Yayınevi.

ARMAOĞLU, Fahir (1993). 20. yy. Siyasi Tarihi (1914-1980), 9. Basım, Ankara: Türkiye İş Bankası Kültür Yayınları.

ATLI, Cengiz (2014). “Kore Savaşı Ve Kore Savaşına Iğdır'dan Katılanlar”, Trakya Üniversitesi Sosyal Bilimler Dergisi, 16(1): 427-444.

BÖLÜKBAȘI, Deniz (2005). Türk Siyasetinde Anadolu Fırtınası Osman Bölükbaşı, İstanbul: Doğan Kitap.

BULUT, Sedef (2008). "Sovyet Tehdidine Karşı Güvenlik Arayışları I. ve II. Menderes Hükümetlerinin(1950-1954) NATO Üyeliği ve Balkan Politikası", Atatürk Yolu Dergisi, 41(11): 35-61. İmge Kitabevi.

DP Tüzük ve Program (1949). Ankara.

DURAK, Gökhan (2015). "Türk ve Dünya Basınında Kore Savaşı ve Türkiye”, Uluslararası Sosyal Araştırmalar Dergisi, 36(8): 323- 339.

ERIM, Nihat(8 Aralık1950). “ Birbirine Karıştırılan Meseleler”, Ulus.

ERIM, Nihat (9 Aralık 1950).“Anayasa Bakımından”, Ulus. 
BAĞCI, Hüseyin (1990). DP Dönemi Dış Politikası, Ankara: İmge Kitabevi.

ERTEM, Barış (2009). "Türkiye-ABD İlişkilerinde Truman Doktrini Ve Marshall Planı", Balıkesir Üniversitesi Sosyal Bilimler Enstitüsü Dergisi, 21(12): 377397.

KENNEDY, Paul (1998). Büyük Güçlerin Yükseliş ve Çöküşleri, çev. Birtane KARANAKÇI, 7. Basım, Ankara: Türkiye İş Bankası Kültür Yayınları.

Kore'de Türk Muharebeleri (2012). Ankara: Genel Kurmay Personel Başkanlığı ATASE Daire Başkanlığı Yayını.

KUŞOĞLU, Baran (2011). "Türk Anayasa Hukukunda Silahlı Kuvvetlerin Yurt Dışına Gönderilmesine Dair Tezkereler" Yasama Dergisi, 17: 5- 38.

NADİ Nadir (29 Temmuz 1950). "Haklı ve Haksız", Cumhuriyet.

ÖZDEMİR Emin- ŞENDİL Fatih (2016). "Soğuk Savaş Dönemi Algı ile Gerçek Arasında Bir İmge Olarak Türk Solu; Demokrat Parti'nin Sol Hareketlere Yaklaşım”, CTAD, 23: 337-369.

ÖZTÜRK, Kazım (1968). Türkiye Cumhuriyeti Hükümetleri ve Programlarl, İstanbul: Ak Yayınları.

Resmi Ziyaret, Türkiye Cumhurreisi Celal Bayar'ın Birleşik Amerika'yı Ziyareti'nin Hikâyesi Ocak-Mart 1954 (Tarihsiz), Ankara.

SADAK, Necmettin (9 Ağustos 1950). “Türkiye’nin Kore’ye Yardımı”, Akşam.

Türk Dış Politikası, Kurtuluş Savaşından Bugüne Olgular, Belgeler, Yorumlar 1919-1980 (2003). Edt. Baskın ORAN, İstanbul: İletişim Yayınları. Vakit.

US Asım (24 Kasım 1950).“DP Hükümeti Mecliste Gensoruya Davet Ediliyor”,

YAMAN, Ahmet Emin (2005). "Kore Savaşı'nın Türk Kamuoyuna Yansıması", Ankara Üniversitesi Türk Inkılâp Tarihi Enstitüsü Atatürk Yolu Dergisi, (37-38) : 231245. 